\title{
Research Paper \\ Effectiveness of Cognitive Emotional Regulation Training on Emotional Knowledge and Emotional Control of Poorly Supervised Students
}

Zahra Motahari Nasab ${ }^{* 1}$, Fateme Alsadat Mirhoseini², Moslem Asli Azad ${ }^{3}$

1. M.A. in School Counseling, Faculty of Psychology and Educational Sciences, Kharazmi University, Tehran, Iran

2. M.A. in Educational Psychology, Faculty of Psychology and Educational Sciences, University of Tehran, Iran

3. Ph.D. of Psychology, Isfahan (Khorasgan) Branch, Islamic Azad University, Isfahan, Iran

Citation: Motahari Nasab Z, Mirhoseini FA, Asli Azad T. Effectiveness of cognitive emotional regulation training on emotional knowledge and emotional control of poorly supervised students. Quarterly Journal of Child Mental Health. 2020; 6(4): 97-107.

http://dx.doi.org/10.29252/jcmh.6.4.10

\section{A R T I C L E I N F O}

Keywords:
Cognitive emotional
regulation training,
knowledge and
emotional control,
poorly supervised
students

Received: 27 Mar 2018 Accepted: 12 Sep 2018 Available: 4 mar2020

\section{A B S T R A C T}

Background and Purpose: Children and teenagers who are poorly supervised, experience different psychological traumatic damages. These students have inappropriate developmental background that makes them prone to suffering from psychological and emotional disturbances. Therefore, the purpose of this study was to investigate the effectiveness of cognitive emotion regulation training on emotional knowledge and emotional control of poorly supervised students.

Method: The research method was semi-experimental with pre-test and post-test with control group. The statistical population of this study consisted of all poorly supervised students between the ages of 12 to 16 years old in the academic year of 2017-18. The sample consisted of 30 people who were selected by purposeful sampling and were assigned to experimental and control groups. The experimental group received cognitive emotion regulation intervention in eight 90 -minute sessions over two and a half months, while the control group did not receive this intervention during the research process. Questionnaires used in this study included Emotional Control Questionnaire (Roger and Nesshoever, 1987) and Emotional Knowledge Test (Izard et al., 2003). The data were analyzed using SPSS 23 software using covariance analysis.

Results: The results of data analysis showed that cognitive emotion regulation was effective on emotional knowledge and emotional control of poorly supervised students $(\mathrm{p}<0.001)$. The effect size also showed that $84 \%$ and $77 \%$ of changes in emotional knowledge and emotional control of poorly supervised students, respectively, were explained by cognitive emotion regulation intervention.

Conclusion: Cognitive emotion regulation using techniques such as recognizing different types of emotions, teaching ways to reduce negative emotions, conscious attention to current emotions, reevaluating and expressing positive and negative emotions, and training to change negative emotions can affect the emotional processing and emotional control of poorly supervised students.

\footnotetext{
* Corresponding author: Zahra Motahari Nasab, M.A. in School Counseling, Faculty of Psychology and Educational Sciences, Kharazmi University, Tehran, Iran.

E-mail addresses: Motahari1355@gmail.com
}

2476-5740/ (C) 2019 The Authors. This is an open access article under the CC BY-NC-ND license (https://creativecommons.org/licenses/by-nc-nd/3.0/). 


\title{
اثربخشى نظمجويى شناختى هيجان بر دانش هيجانى و مهار هيجانى دانش آموزان بدسريرست
}

\author{
زهر ا مطهرىنسب"'، فاطمهالسادات مير حسينى '، مسلم اصلى آزاد؟

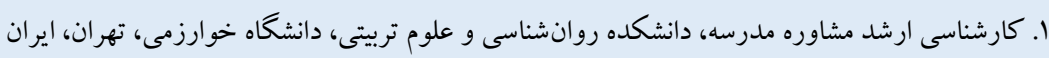

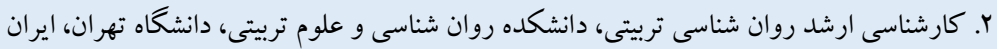

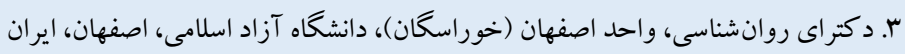

جكي"

زمينه و هدف: كود كانى كه بدسريرست هستند، آسيبهاى روانشناختى گوناكونى را در سالهاى بعد تجربه مى كنند. اين كود كان از

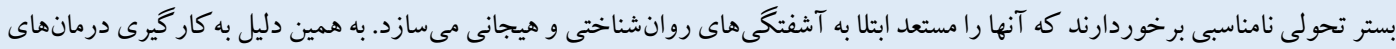

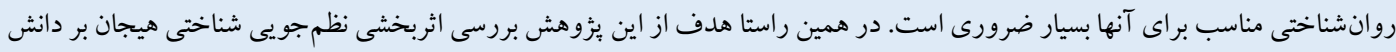

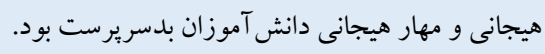

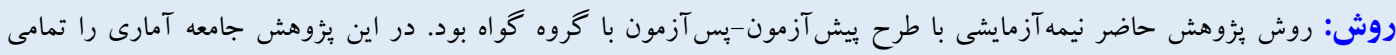

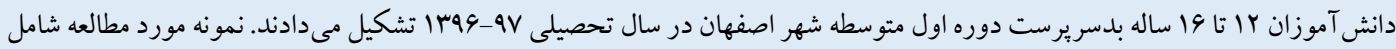

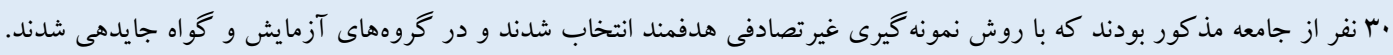

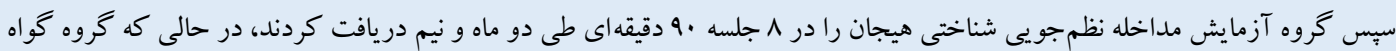

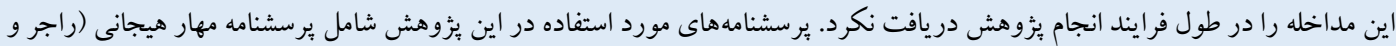

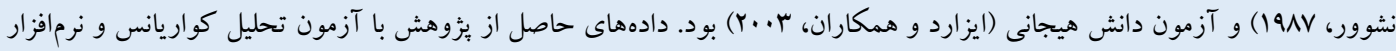
آمارى SPSS يافتها: نتايج حاصل از تحليل دادهها نشان داد كه نظمجويى شناختى هيجان بر دانش هيجانى و مهار هيجانى دانش آموزان بدسريرست مؤثر

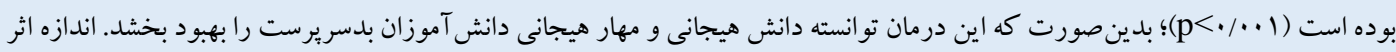

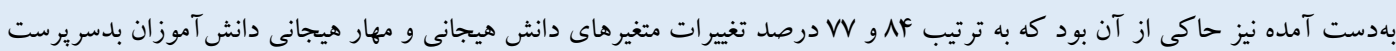
توسط مداخله نظم جويى شناختى هيجان تبيين مىشود. نتيجه كيرى: نظمجويى شناختى هيجان با استفاده از روشهايى مانند شناخت انواع هيجان، آموزش راههاى كاهش هيجانات منفى، توجه

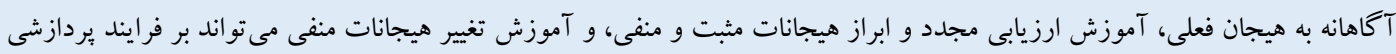

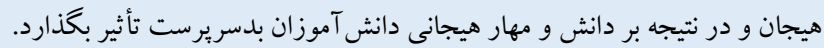

مشخصات مقاله

كليدوازهها:

نظم جويى شناختى هيجان،

دانش هيجانى،

مهار هيجانى،

دانش آموزان بدسريرست

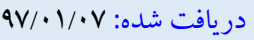
يذيرفته شده:

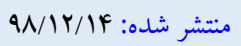

* نويسنده مسئول: زهرا مطهرىنسب، كارشناسى ارشد مشاوره مدرسه، دانشكده روانشناسى و علوم تربيتى، دانشكاه خوارزمى، تهر ان، ايران.

رايانه: Motahari1355@gmail.com

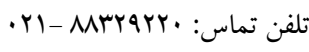


كه هيجان در آن مناسـب و لازم اسـت (ه). فرزندان بى و بدسريرست به علت فقدان يا كمبود دانش هيجانى مناسب در شناخت هيجانات مثبت و

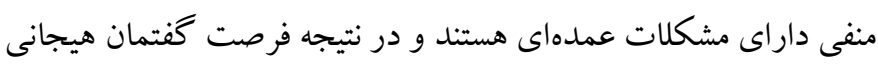

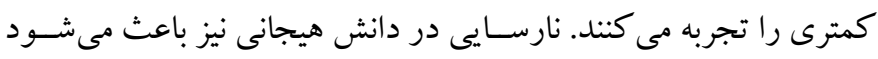

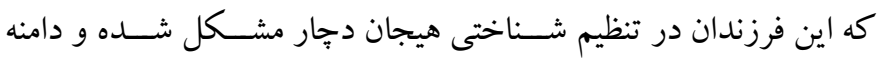

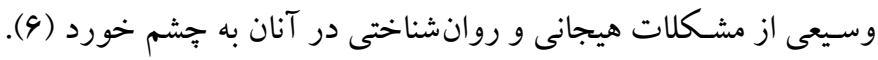

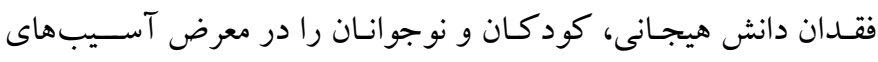

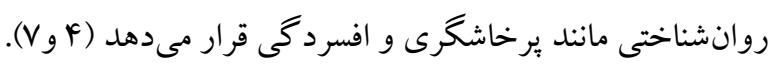

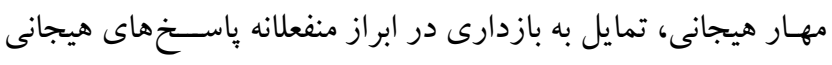

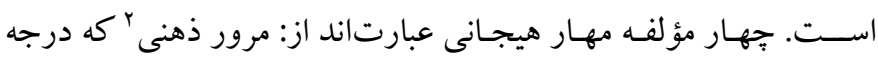

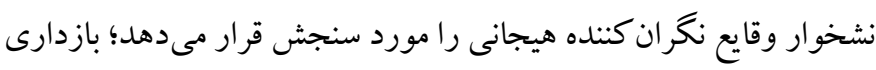

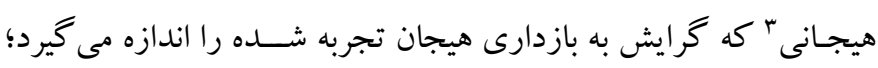

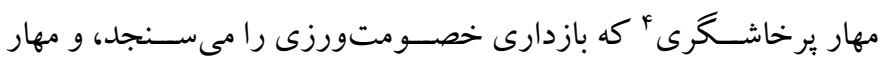

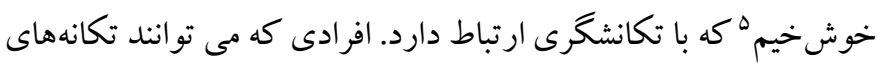

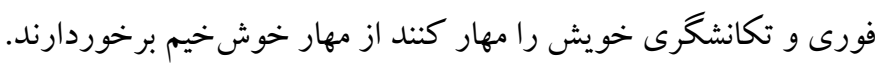
بدين ترتيب مى توان كفت كه افراد داراى مهار هيجانى مى توانند از بروز

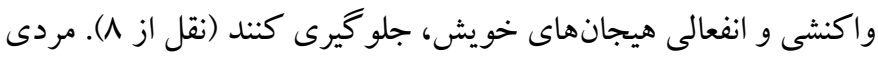

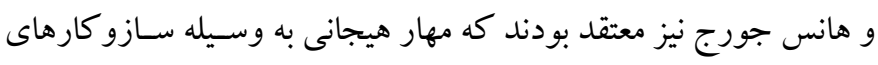

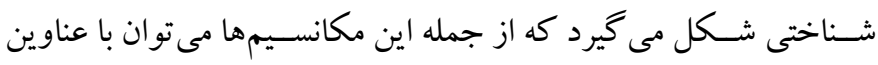

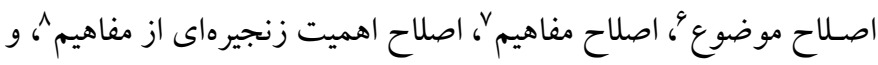
اصلاح آستانه عقبنشينى هياد كرد (9) (9). نارسايى در دانش و تنظيم شناختى هيجان در كود كان و نوجو انان بد

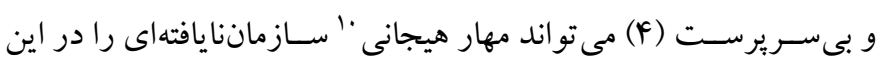

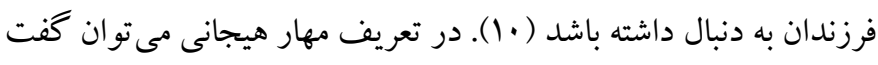

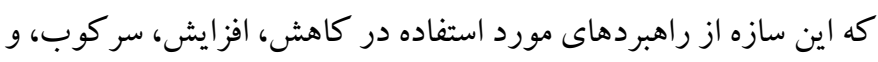

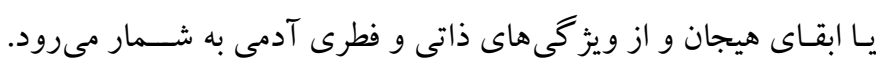

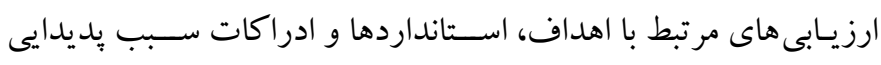

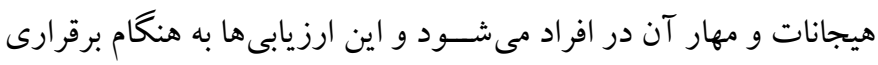

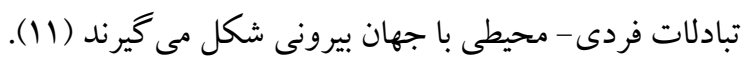

6. Altering Topics

7. Altering concepts

8 . Altering the importance of a chain of concepts

9 . Altering threshold for disengagement

10. Emotional control
مقلدمه

كود كـان و نوجو انـانى كـه بـا يـك والــ زنــــى معى كنند و يا كود كان

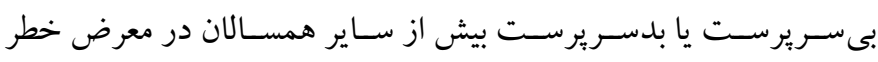

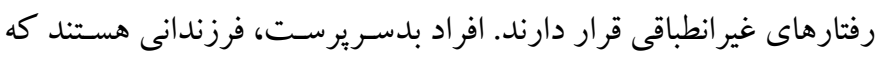

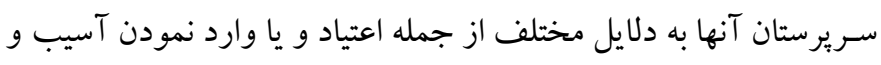

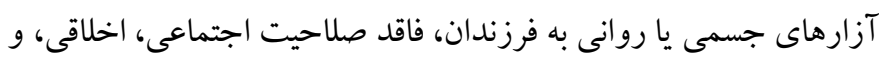

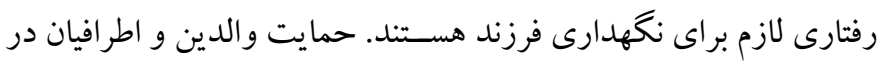

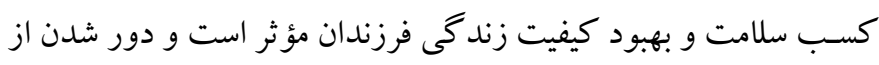

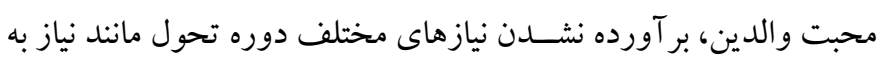

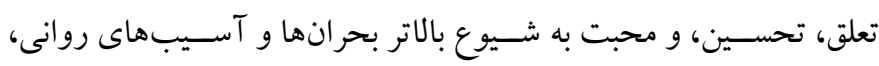

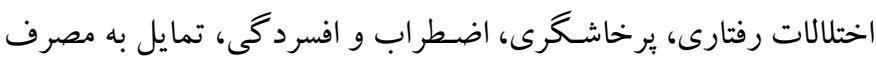

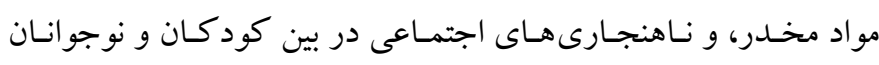

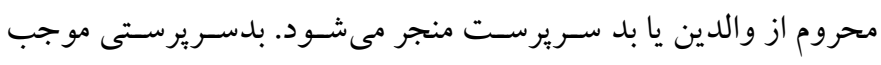

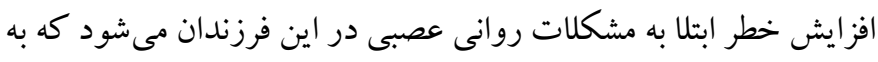

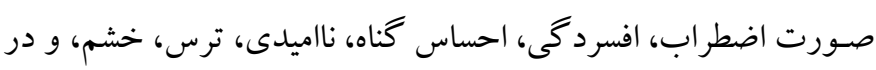
نهايت در كاهش شادزيستى آنها نمود بيدا مى كند (1)

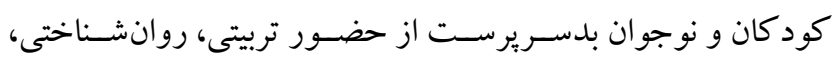

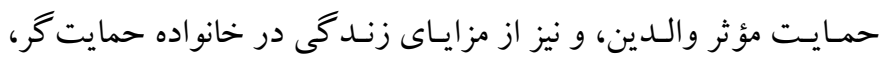

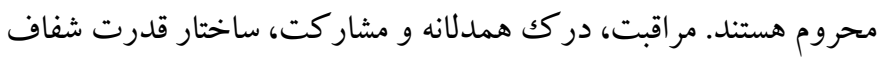

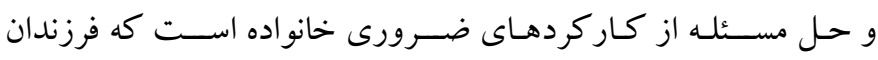
بدسريرست از اين نعمت محروم هستند (Y). رشد و تحول فرزندان بدون

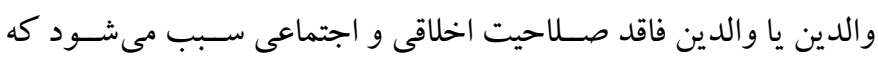

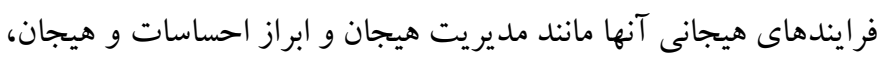

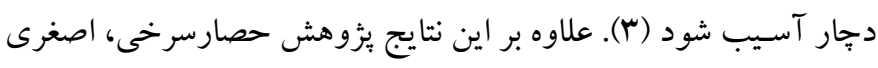

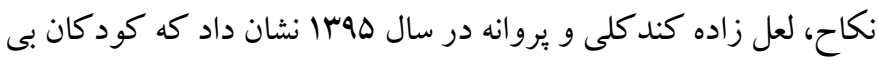

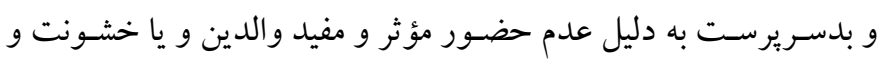

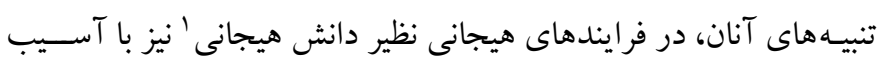

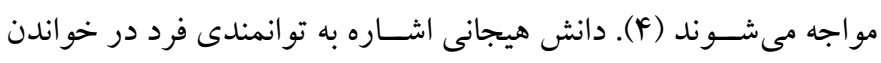
نشانهاى هيجانى و تشخيص حالات هيجانى در موقعيت هايى اشاره دارد

1. Emotional knowledge

2. Rehearsal

3 . Emotional inhibition

4. Aggression

5 . Benign control 
اسـت كه آيا آموزش نظم جويى شناختى هيجان بر دانش و مهار هيجانى اين دانش آموزان تأثير دارد؟

\section{روش} الف) طرح بثزوهش و شــــــت كنند كان: روش اين بزوهش از نوع

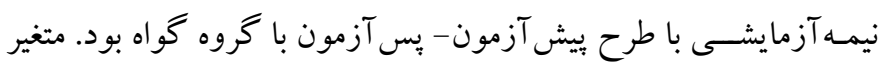

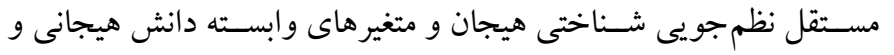

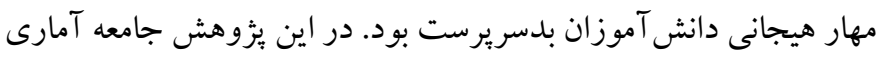
را تمامى دانش آموزان بدسريرست مشـغول به تحصيل در مدارس دوره

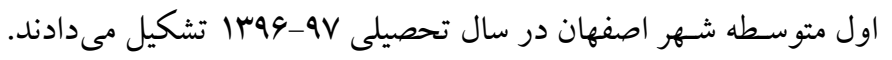

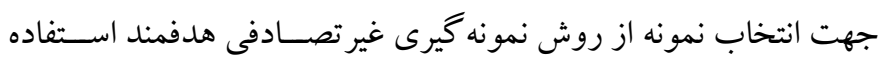

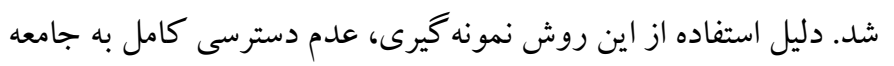

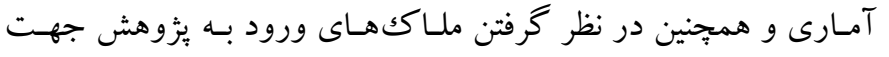

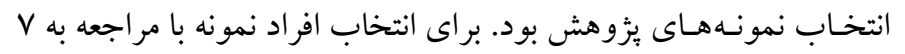

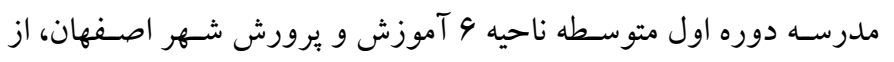

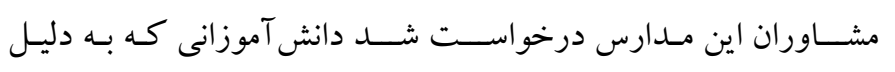
بدسريرستى داراى يرونده مشـاوره هستـند را معرفى كنند. دليل انتخاب

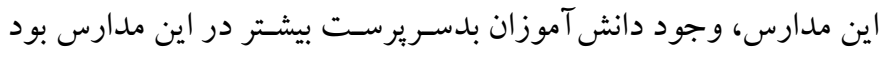
(بنا بر اظهار مشــاوران اين مدارس). از اين مدارس تعداد سه دانش آموز

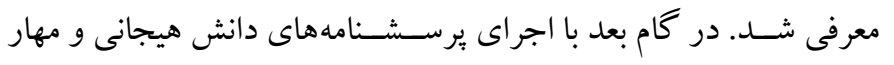

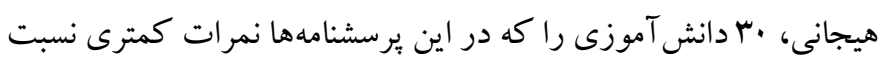

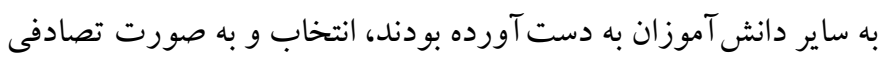

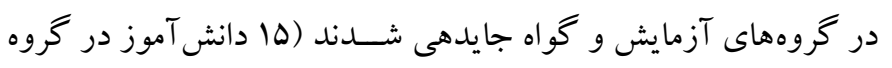

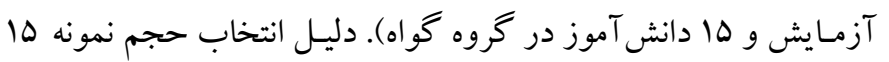
نفر براى هر گروه، رجوع بـه منـابع علمى معتبر (YY) دربـاره تعداد نمونه

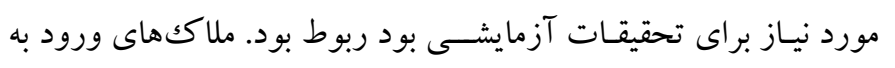

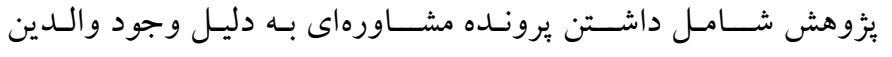
آســيبرســان، مشــكلات رفتارى و هيجانى همانند نافرمانى، رفتار هاى

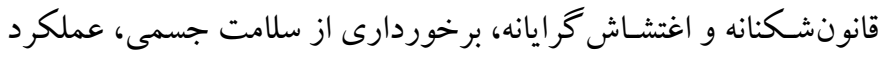

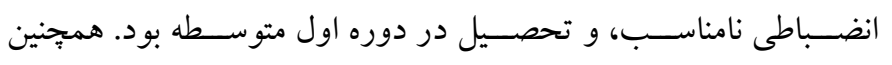

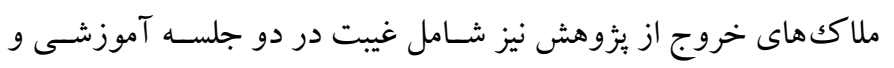

جهت بهبود مؤلفه هاى روانشناختى، اجتماعى، و هيجانى كود كان و نوجو انان بدسـريرست، تاكنون روشهاى آموزشى و درمانى كوناگونى

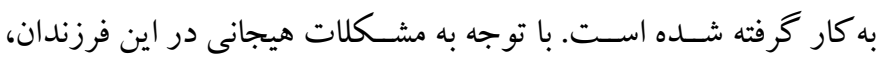

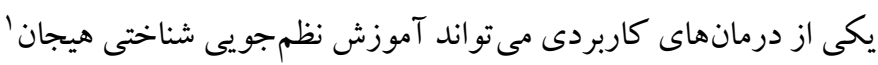
باشـــ. اعتقاد بر اين اسـت كه راهبردهاى نظم جويى شــناختى هيجان به افراد كمكك مى كنـد تا بر انخيختخى ها و هيجانهاى منفى را تنظيم كنند

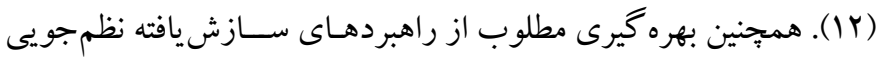
شـناختى هيجان مانند ارزيابى مجدد باعث كاهش احســاســات منفى و و افزايش احساسات مثبت و رفتار سازشيافته مىشود (rار). به طور كلى يافته هاى بثزوهشـى متعدد بيانكر رابطه قوى راهبردهاى

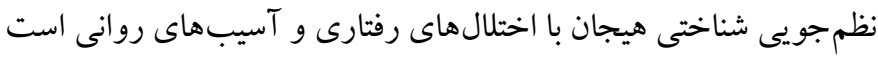

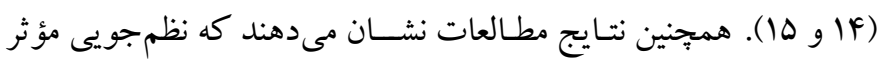

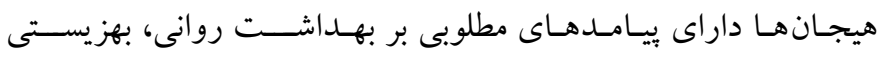
روانشـناختى، سلامت جسمانى، و روابط بينفردى هستند (19). علاوه بر برك اين نتايج مطالعات متعدد نشاندهنده ويامدهاى اثربخش روش نظ نظم جويى

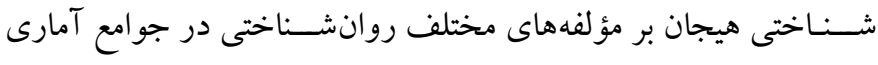
كوناكون بوده است. براى مثال بر اساس نتايج بثوهش هاى مختى مختلف (IV)

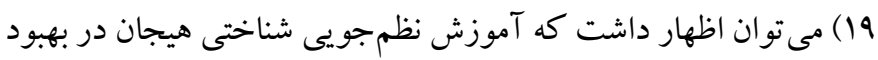

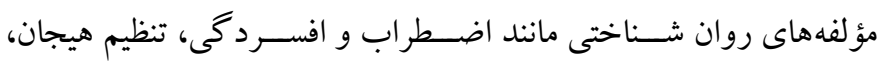

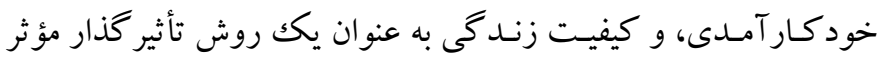

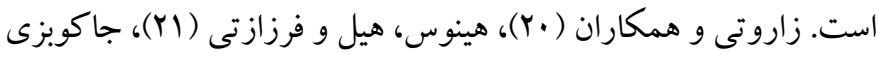

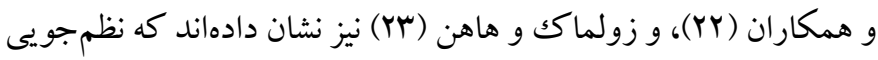

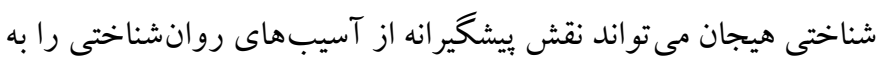
دنبال داشته باشد.

بدين ترتيب از يكك سو با توجه به آسيبهاى روانشناختى و هيجانى

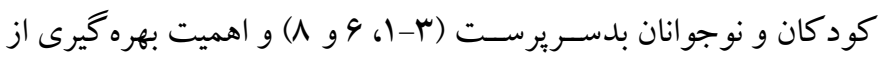

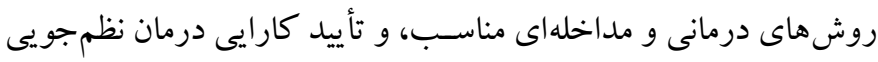

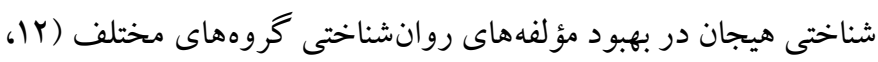

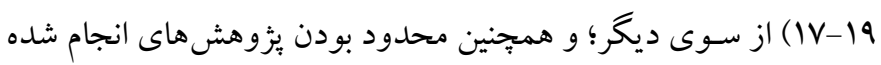
دربـاره اثربخشـى نظم جويى شــــاختى هيجان بر دانش و مهار هيجانى دانش آموزان بدسريرست، مسئله اصلى يزٔوهش حاضر بررسى اين نكته 
و تطبيق حالات هيجانى را مى سنجد. اين آزمون جهار بخش دارد، بخش اول، تطبيق حالات هيجانى است كه به آزمودنى يك جهره هيجانى نشان داده مى شــود و ســـس از او خواسـته مى شـود تا جهرهاى را كه حالت هيجانى مشابه با آن را دارد، از ميان جهار حالت جهره، نشان دهد. بخش دوم، دانش موقعيت هيجانى است كه آزمودنى بايد يكك رويداد فراخوان هيجان را كه به صـورت داسـتان برايش تعريف مىشـود با يكى از جهار حـالـت جهره، تطبيق دهد. بخش ســوم، نام گذارى حالت هيجانى جهره اسـت كه به آزمودنى يكك جهره هيجانى نشـان داده مىشـود و كود كك بايد بكويد كه جֶه احساسى دارد. بخش جهارم، تشخيص حالات هيجانى است كه آزمودنى بايد هيجانهايى را كه توسط آزمونخر خوانده مىشود

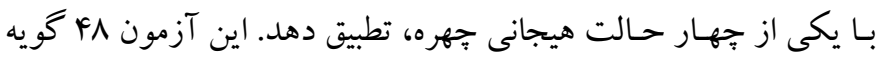
دارد كه كودكك و نوجوان بايد با توجه به تصــاوير اسـتاندارد شــده از حالات جهره ويكى از جهار هيجان يايه (شـامل شــادى، غم، خشــم، و ترس)، به سوالات مربوطه يِاسخ دهد ( • (1). نمره گذارى اين آزمون به اين صورت است كه اكر كودكك در بخش اول، دوم، و جهارم درست ياسخ داد نمره ا و اگر اشـتباه ياسخ داد نمره صفر مى گيرد. در بخش سوم اگر

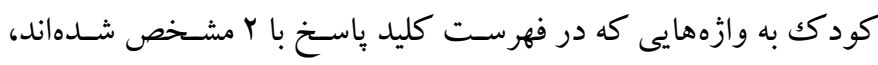
اشـاره كند نمره Y، اكر به وازههايى كه با ا مشـخص شدهاند، اشاره كند نمره ا، و اخر به وازههايى غير از وازههاى فهرست اشاره كند، نمره صفر

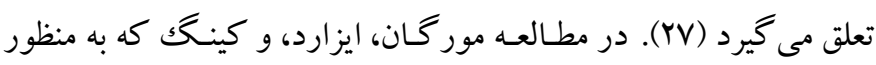
بررسى اعتبار و روايى انجام شد، ضريب آلفا براى نمره كل آزمون تطبيق

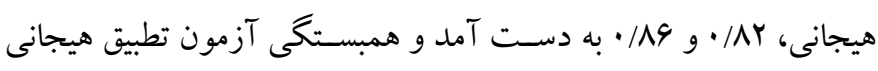
(نمره كـل) بـا ديخر مقيـاسهـاى دانش هيجانى مانند مصــاحبه هيجانى

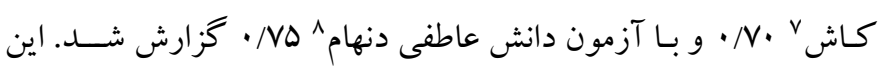
يثزوهشخران همجنين روايى اين يرسشنامه رانيز مطلوب گز ارش كردهاند. حصــارســرخى و همكار ان طى يكك مطالعه مقدماتى هايايى اين ابزار از طريق آزمون باز آزمون بر روى ها نفر از كود كان ايرانى به فاصسله يك

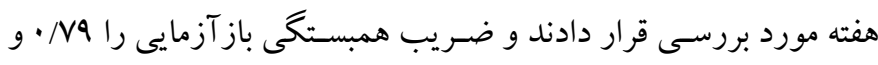
آلفاى كرونباخ را سی/ • كزارش كردند (F).

5. Buss-Durkee Hostility inventory

6. Izard

7. The Kusche emotional inventory

8. Denham's affective knowledge test
عدم همكارى و انجام ندادن تكاليف مشـخص شــده در دوره آموزشـى بود. للازم به ذكر اسـت كه افراد نمونه داراى دامنه سـنى با تا ها سـال بودند كه در اين بين دامنه سـنى با سـال داراى بيشترين فراوانى بود درصد). همجنين سطح تحصيلى افراد نمونه در دوره اول متوسطه بود كه بيشترين تعداد فراوانى مربوط به كلاس هشتم بود (سام درصد).

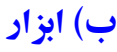
1. برسشنامه مهار هيجانى ': راجر و نشوورب(19AV) ساختار اوليه يرسشنامه مهار هيجانى را تنظيم و راجر و نجاريان (1919) آن را تجديدنظر كردند. لازم به ذكر اسـت كه در اين ئزوهش، يرسـشـنامه تجديدنظرشـده به كار

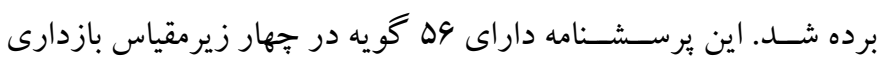
هيجانى، مهار يرخاشـرى، نشـخوار، و مهار خوش خيمَّ (هر يكك داراى |f غلط اســت كـه نمره يـك و صــفر بـه آنها تعلق مى كيرد. دامنه نمرات يرسـشـامه بين صـفر تا وهاست. در اين برسشنامه نمره بالاتر بيانكر مهار هيجانى بالاتر اســت. رفيعىنيا (به نقل از Yo) ضـريب آلفاى كرونباخ را براى كل مقياس 91/ • و براى زير مقياسهاى ياد شــلده به ترتيب • ل/ •،

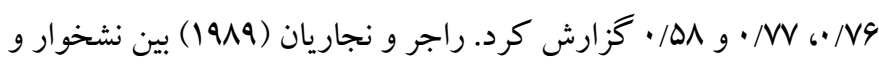
روانرنجورخويى برسشنامه شخصيتى آيزنك ثا)، بين مهار يرخاشخرى و و

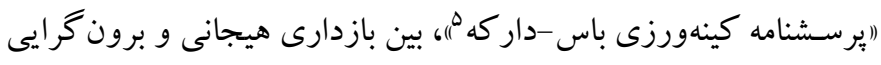

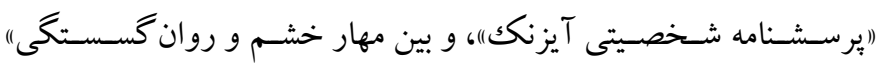

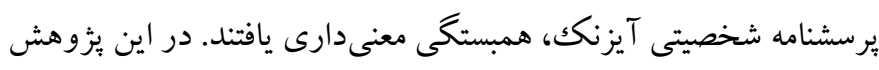
ضـريب اعتبار اين يرسـشـنامه با استفاده از روش آلفاى كرونباخ •19/ • به

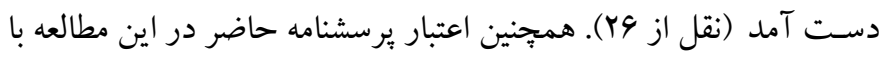
استفاده از ضريب آلفاى كرونباخ بر اى زيرمقياسهاى بازدارى هيجانى،

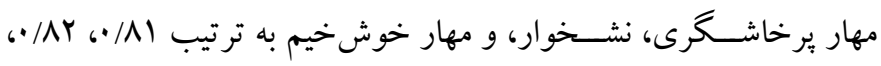

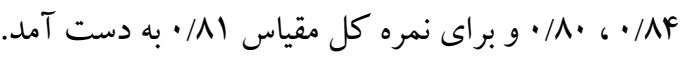
r. آزمون دانش هيجانى: اين آزمون توسـط ايزاردو و همكاران در سـال

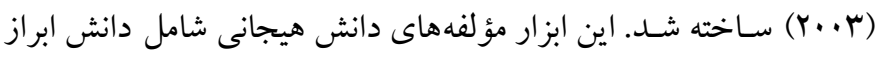
هيجانى (تشخيص و نام گذارى حالات هيجانها)، دانش موقعيت هيجان،

1. Emotional control questionnaire (ECQ)

2. Roger and Nesshoever

3. Benign control

4. Eysenck personality questionnaire 
ج) برنامه مداخلهاى: برنامه مداخلهاى در بزّوهش حاضر بر گرفته از

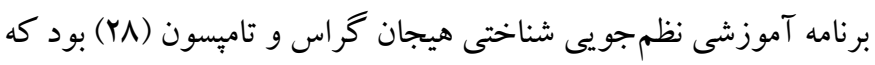

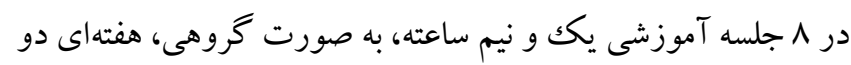

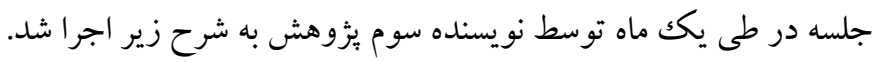

جدول ا: خلاصه جلسات آموزشى نظمجويى فرايندى هيجان

\begin{tabular}{|c|c|c|}
\hline شرح جلسه & هدف & جلسه \\
\hline 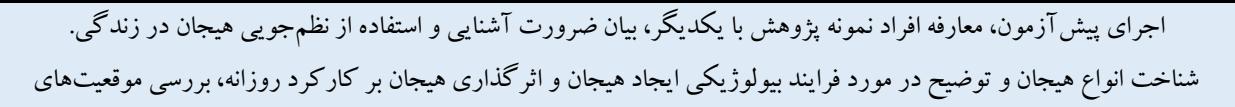 & معارفه افراد & يكم \\
\hline برانكيزاننده و نوع بروز هيجانات از طريق آموزش تفاوت عملكرد هيجانات و اثرات كو تاهمدت و بلند مدت آنها، نوشتن انواع هيجانات & تعريف و شناخت هيجانها & 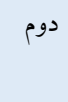 \\
\hline آموزش آكاهى از تجربيات مثبت، ايجاد تجربههاى مثبت از طريق تجسم ذهنى صحنه هاى شادى بخش و غفلت از نخر انى، تغيير توجه، & روشهاى افزايش تجربههاى مثبت & 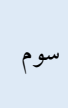 \\
\hline 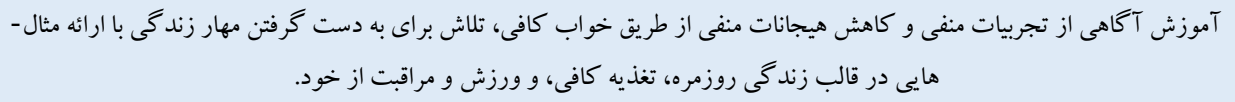 & روش هاى كاهش هيجانات منفى & جهارم \\
\hline 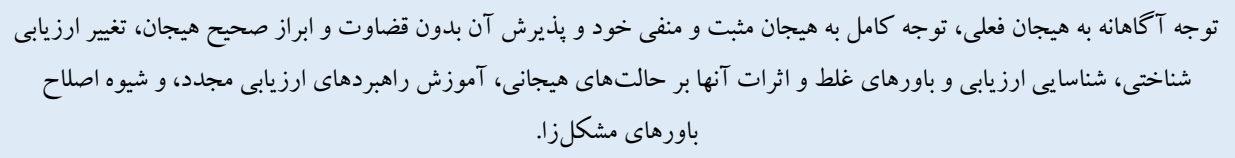 & خود آكاهى هيجانى & ينجم \\
\hline 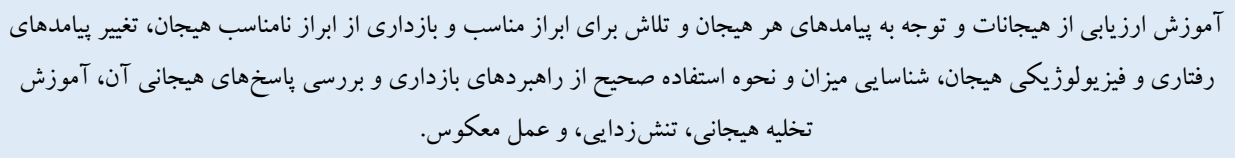 & ارزيابى مجدد و ابراز هيجانات مثبت و منفى & ششم \\
\hline 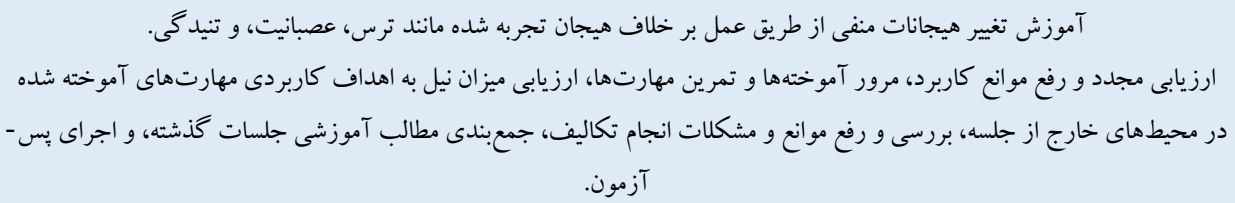 & جمع بندى و اختتام جلسات & هiتم \\
\hline
\end{tabular}

شر كت در برنامه مداخله كسب شده و از تمامى مراحل اجراى آن، آكاه شدند. همجينين به هر دو كروه اطمينان داده شد كه اطلاعات آنها محرمانه باقى مى ماند و به درج نام نيازى نيست. به افراد گروه گو اه نيز اطمينان داده شد كه آنان نيز يس از اتمام فرايند يزوهشى، اين مداخلات را دريافت خواهند كرد. در اين يثوهش براى تجزيه و تحليل دادهها از دو سطح آمار توصيفى و اسـتنباطى اسـتفاده شـده اسـت. در سـطح آمار توصسيفى از ميانگين و انحر اف استاندارد و در سـطح آمار استنباطى از آزمون شـاييرو-ويلك لـ جهـت بررسـى نرمـال بودن توزيع متغيرهـا، آزمون لوين براى بررسـى برابرى واريانس ها، همجنين از تحليل كواريانس براى بررسـى فرضــيه
د) روش اجرا: جهت انجام يُزوهش ابتدا هماهنكَىهاى للازم با مديران مدارس منتخب آموزش و برورش ناحيه آموزش و برورش 4 اصفهان كرفته شد. سيس با مراجعه به مدارس انتخاب شده، افراد نمونه طى رضايت كتبى و به شرحى كه در بخش روش آمده است انتخاب شدند و به تصادف در گروههاى آزمايش و كواه جايدهى شدند. لازم به ذكر است كه يرسشنامههاى بزٔوهش به صورت گروهى بر روى افراد حاضر در يزٔوهش اجرا شد. در مرحله بعد گرووه آزمايش مداخله نظمجويى شناختى هيجان (YF) را در N جلسه آموزشى يك و نيم ساعته، هفتهاى دو جلسه در طى يكك ماه مطابق با جدول ا دريافت كرد، در حالى كه گروه گو اه مداخلهاى رادريافت نكرد. در يايان هر دو گروه مورد ارزيابى مجدد قرار كرفتند. جهت رعايت اخلاق در بئوهش رضايت دانشآموزان براى 


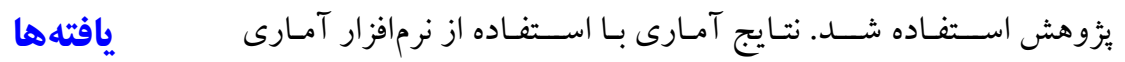

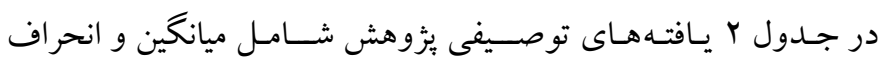
س r SPSS تجزيه و تحليل شد.

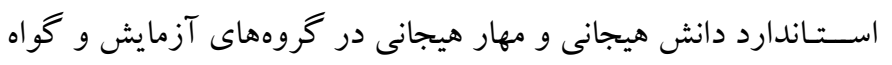

$$
\text { كزارش شده است. }
$$

جدول ז: ميانكين و انحراف استاندارد دانش هيجانى و مهار هيجانى در كروههاى آزمايش و كواه

\begin{tabular}{|c|c|c|c|c|c|c|c|}
\hline \multirow{2}{*}{ نرماليتى دادهها } & \multicolumn{2}{|c|}{ هָ پَزمون } & \multirow{2}{*}{ نرماليتى دادهها } & \multicolumn{2}{|c|}{ بيش آزمون } & \multirow{2}{*}{ كروهاها } & \multirow{2}{*}{ مؤلفهها } \\
\hline & انحر اف معيار & ميانكين & & انحراف معيار & ميانكين & & \\
\hline$\cdot / r \Delta$ & $\Delta /{ }^{\prime}$ & $\mu F / F$. & $\cdot / F F$ & $f / r \Delta$ & $r \Delta / \Delta r$ & خروه آزمايش & \\
\hline$\cdot / 1 \Lambda$ & F/VD & $r 91.9$ & . & $\Delta / F q$ & $r \Delta / q T$ & گرووه گواه & دانش هيجانى \\
\hline$\cdot / r r$ & $9 / 19$ & rV/A. & .1 .9 & $F / \wedge \Delta$ & $r \Delta / A$. & گرووه آزمايش & \\
\hline$\cdot / \mu$. & $F / I r$ & $r V / \pi r$ &.$/ 10$ & GNY & $r \Delta / 94$ & گروه گواه & مهار هيجانى \\
\hline
\end{tabular}

آزمايش و گروه گواه در متغيرهـاى وابسـتـهـ (دانش هيجـانى و مهـار

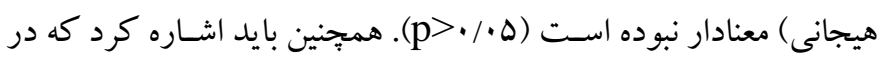

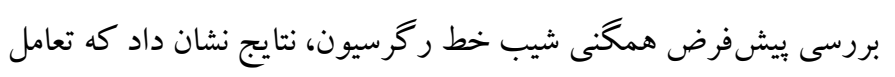

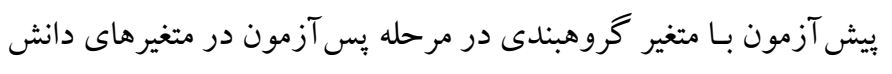

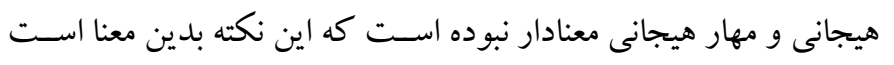

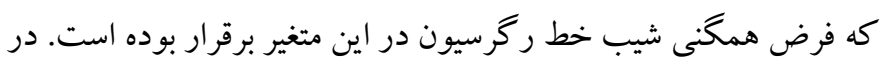

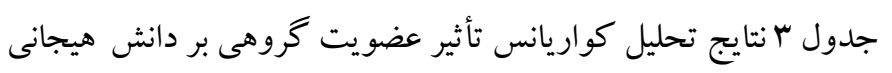

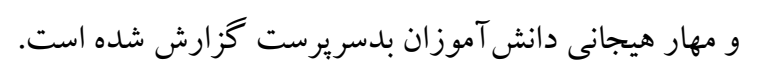

قبـل از ارائـه نـتـايج تحليـل آزمون كواريـانس، يِيشفرضهـاى

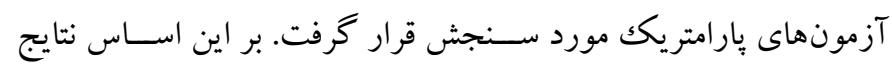

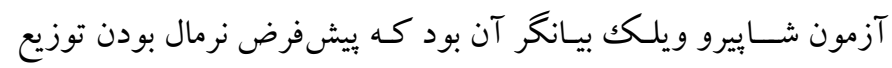
نمونسهاى دادههـا در متغيرهـاى دانش هيجـانى و مهار هيجانى در مر احل

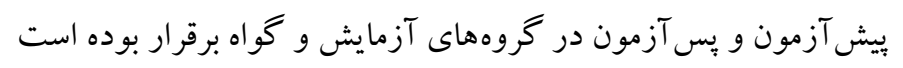

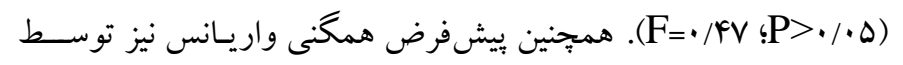

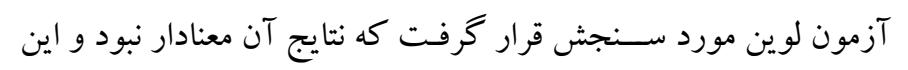

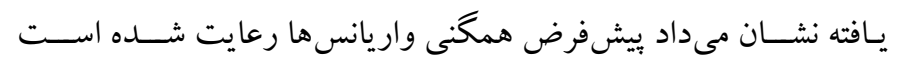

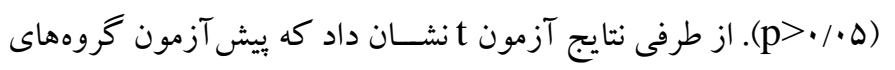

جدول با: تحليل كواريانس تأثير عضويت كروهى بر دانش هيجانى و مهار هيجانى دانش آموزان بدسربرست

\begin{tabular}{|c|c|c|c|c|c|c|c|c|}
\hline توان & اندازه اثر & معنادارى سطح & $\mathbf{F}$ & مجذانغين & درجه آزادى & مجموع مجذورات & شاخصهاى آمارى متغيرها & متغير ها \\
\hline$\cdot / \cdot V$ &.$/ .99$ &.$/ 94$ & $\cdot / Y F$ & $\cdot / \wedge \Delta$ & 1 & $\cdot / \wedge \Delta$ & ي بيش آزمون & \\
\hline \multirow[t]{2}{*}{1} & - /AF & $\cdot / \cdots \cdot$ & $149 / 90$ & $\Delta 19 / v$ & 1 & $\Delta 19 / v$ & عضويت گروهى & دانش هيجانى \\
\hline & & & & $r / \Delta F$ & rV & $9 \Delta / 91$ & خطا & \\
\hline$\cdot / \wedge 1$ & $\cdot / r F$ & $.1 . .9$ & N/Vr & $V W / \Delta \Delta$ & 1 & $W / \Delta \Delta$ & ي بيش آزمون & \\
\hline \multirow[t]{2}{*}{1} & $\cdot / \mathrm{WV}$ & $\cdot / \cdots 1$ & $9 \cdot / v 9$ & $\Lambda \cdot V / \mu F$ & 1 & $\Lambda \cdot V / \mu F$ & عضويت گروهى & مهار هيجانى \\
\hline & & & & N/A 9 & rV & $r F \cdot / I V$ & خطا & \\
\hline
\end{tabular}

بدسـريرست) در مرحله يس آزمون در سـطح خطاى هـ • • شود؛ بنابر اين اين نتيجـه حاصـلـل مى شــود كه با كنترل متغيرهاى مداخله كر، ميانكين نمرات متغيرهاى دانش هيجانى و مهار هيجانى دانش آموزان بدسريرست
بـا توجـه بـه نتـايج جــدول فوق، آموزش متغير مســتقـل (نظمجويى شــاختى هيجان) تو انسـته اسـت باعث ايجاد تفاوت معنادار در ميانگين نمرات متغيرهـاى وابســــه (دانش هيجـانى و مهار هيجانى دانش آموزان 
ســن ديخر اين يـافته مى تواند تأييدى بر يافتهاى قبلى مبنى بر ارتباط

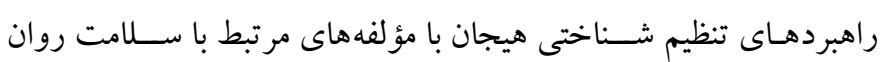

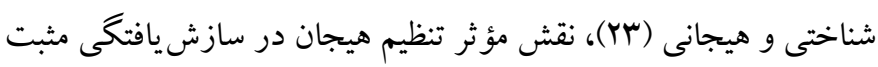

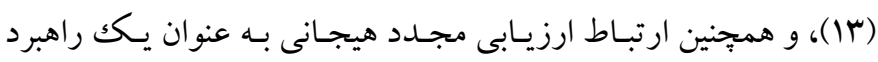

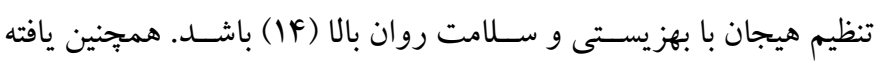

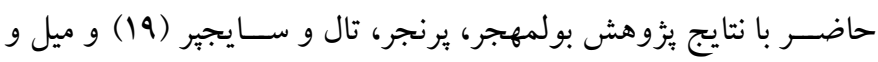

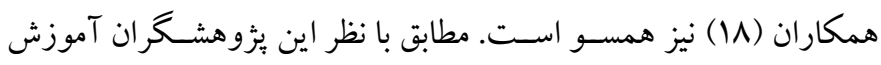

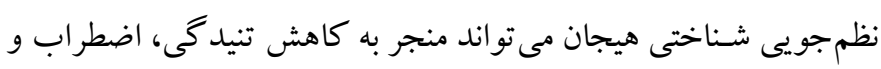

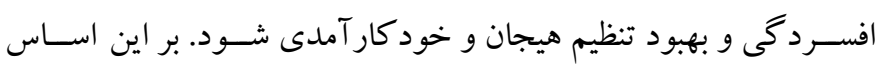

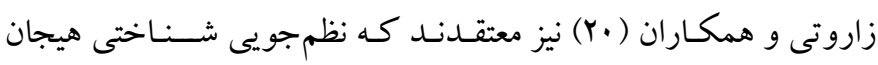

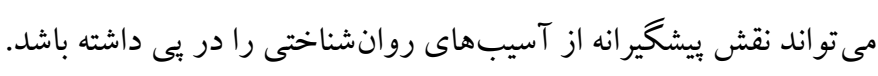

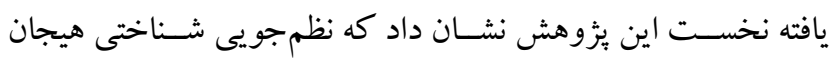

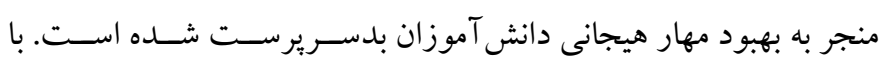

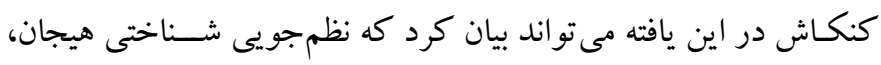

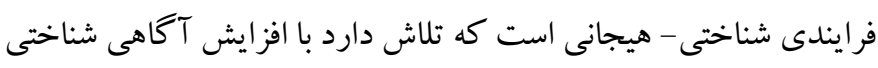

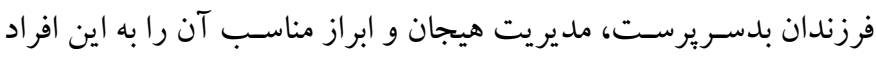

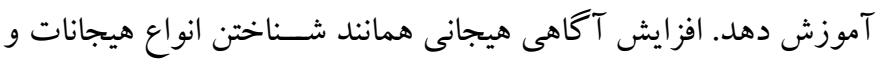

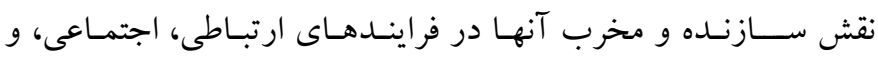

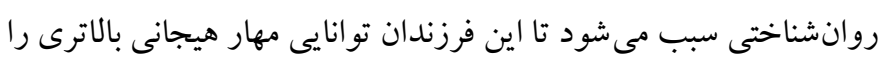

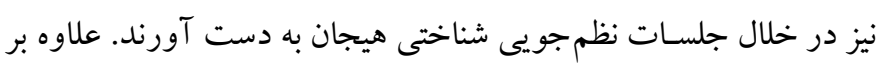

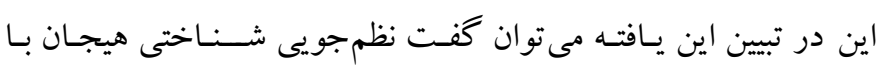

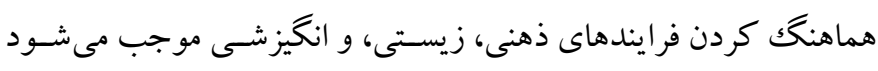

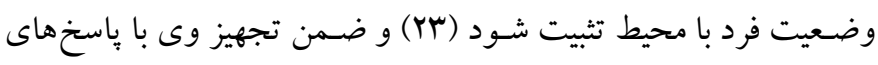
هيجانى ويزه و كار آمد مناسب با مسائل، در نهايت موجب بقدي بقاى جسمانى و اجتماعى مىشود (Y ). بنابراين نظم جويى شناختى هيجان سبب كاهش

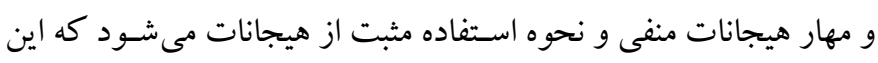

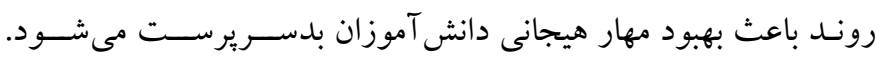

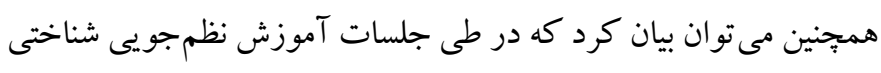

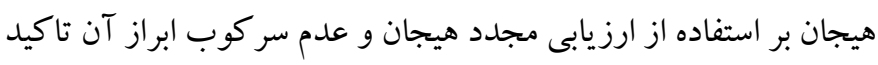

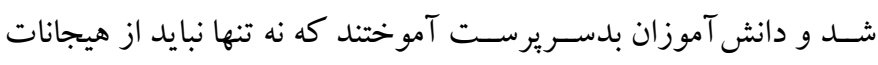

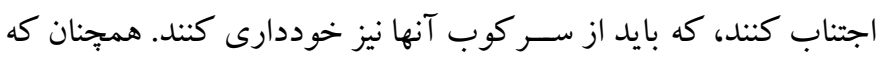

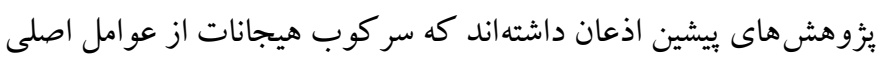

بـا آموزش نظم جويى شــــاختى هيجان، تغيير كرده اســت. مقدار تأثير آموزش نظمجويى شناختى هيجان بر ميزان دانش هيجانى و مهار هيجانى

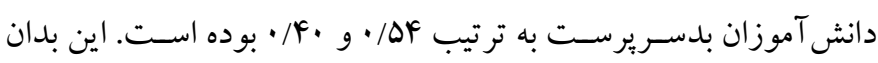

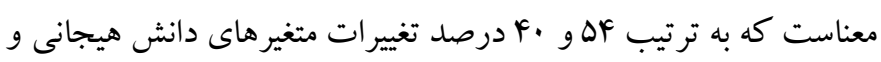

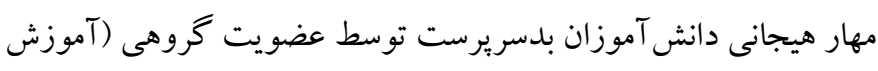

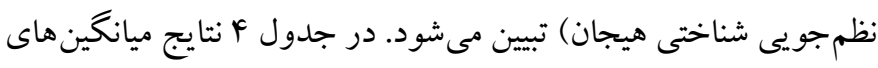
تعديل شده متغيرهاى وابسته گز ارش شده است. تئن

\section{جدول ع: ميانكين هاى تعديل شده متغير هاى وابسته}

\begin{tabular}{|c|c|c|c|}
\hline خطاى استاندارد & ميانكين & كروها & متغير ها \\
\hline$\cdot / 4 A$ & $\mu F / 4 \mid$ & كروه آزمايش & \multirow{2}{*}{ يس آزمون متغير دانش هيجانى } \\
\hline$\cdot / 4 A$ & $r 91.0$ & خروه گواه & \\
\hline$\cdot / W$ & rV/va & گروه آزمايش & \multirow{2}{*}{ پِ آزمون متغير مهار هيجانى } \\
\hline$\cdot / \mathrm{W}$ & $\mathrm{rV} / \mathrm{TV}$ & گروه گواه & \\
\hline
\end{tabular}

جنانكه از نتايج جدول \& مشـخص اسـت نمرات ميانگين تعديل شده متغيرهـاى دانش هيجـانى و مهار هيجـانى در گروه آزمايش از ميانكين

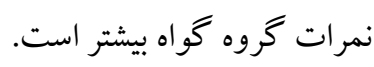

\section{بحث و نتيجه كيرى}

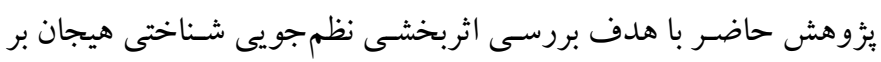

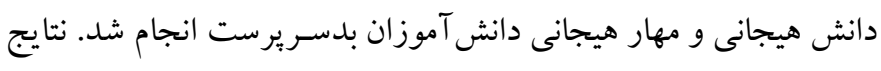

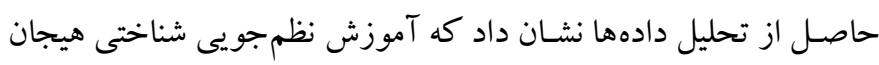
بر دانش و مهار هيجانى اين دانش آموزان مؤثر بوده است. نتايج به دست

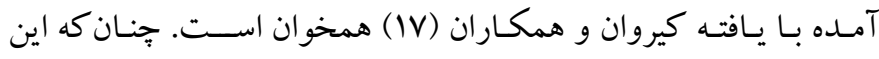

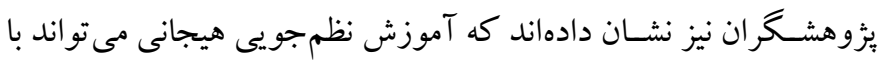

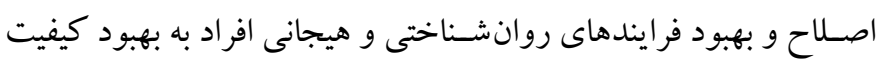

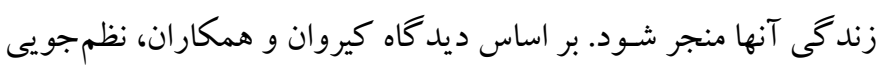
شناختى هيجان فقط كاهش هيجانهاى منفى نيست، كه تعديل، بهسازى، رهان،

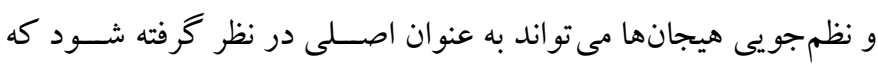
هيجانات مثبت و هنجارمند را نيز دستخوش تغيير و اصلاح كند. هئد همجنين يـافتهـهـاى يزووهش حاضــر با يافته هانيوس، هيل و فرازتى

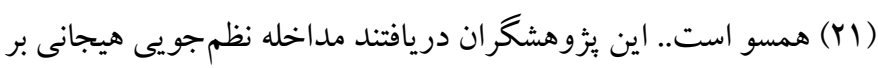

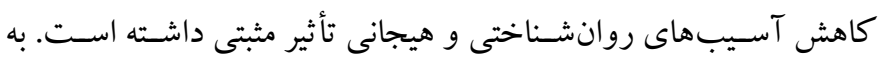


منفى و يذيرش و ابراز به موقع آنها، نقش مهمى در افزايش دانش هيجانى آنها داشته باشد.

و جود برخى متغيرهاى كنترل نشده در اين مطالعه مانند وضعيت مالى خانوادهها، تعداد فرزندان، تحصيلات والدين و موقعيت اجتماعى آنها، و عدم بهره گيرى از روشهاى نمونه كيرى تصـادفى از محدوديتهاى اين يثزوهش بود؛ بنابر اين بيشنهاد مى شود تا براى افزايش قدرت تعميميذيرى نتايج، اين ئزوهش در سـاير شهرها و مناطق و جوامع دار ایى فرهنگ هاى متفاوت و خانو ادههاى با وضـعيت اقتصـادى - اجتماعى مختلف، كنترل

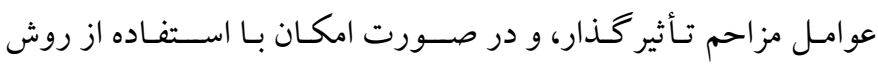
نمونه گيرى تصـادفى اجرا شــود. همجينين در سـطح بثزوهشى بيشــنهاد مىشـود كه طى بثزوهش هاى آتى، كارايى نظم جويى شناختى هيجان در

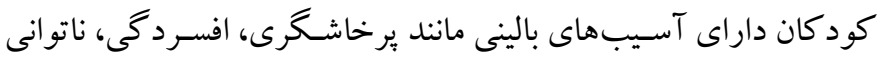
ياد گيرى، و اختلال نارسايى توجه/فزون كنشى نيز انجام شود. بـا توجـه به اثربخشـى نظمجويى شـــاختى هيجان بر دانش و مهار هيجانى دانش آموزان بدسـريرست در اين مطالعه، در سـطح به كار بسـته ييشـــهاد مى شــود تمرين ها و فعاليتهاى نظم جويـى شــناختى هيجان به دانش آموزان بدسـريرسـت آموزش داده شــود و اين برنامه در مدارس (توسط مشـاوران) و به ويثه در مراكز درمانى و روانشناختى آموزش و برورش براى بهبود فرايندهاى هيجانى اين دانش آموزان (شـامل دانش و مهار هيجانى) اجرا شود.

تشكر و قدردانى: اين مطالعه به صورت مستقل اجرا شده است. مجوز اجر اي آن از ســوى اداره آموزش و برورش ناحيه 9 اصـفهان صـادر و تحت نظارت كروه مشـاوره اين ناحيه انجام شـده است. بدينوسيله از دانش آموزان حاضر درور اين مطـالعه و همجينين از مســـولين آموزش و برورش كه اجازه و امكان انجام يثوهش حاضر را فراهم كردند، تقدير و تشكر مىشود. تضــاد منافع: در اين بئوهش هيج گونه تعارض منافع توســط نويســند گان كز ارش نشده است.
و تداومبخش اختلالهاى روانشــناختى افراد مختلف به شــمار مىرود (Y) (I). به علاوه بايد توجه داشـت كه در درمان نظم جويى شناختى هيجان بر آكاهى و شناسايى هيجانات تاكيد زيادى انجام مىشود و اين موضوع به دانش آموزان كمكك مى كند تا ادراكك بيشتر و روشنترى از هيجانات خود داشته و از اين طريق مهار هيجانى افراد، بهبود يابد. يافته دوم يثزوهش حاضــر نشـان داد كه نظم جويى شــناختى هيجان منجر به افزايش دانش هيتجانى دانش آموزان بدسريرسـت شده است. در تبيين اين يافته بايد كفت آموزش نظمجويى شــناختى هيجان اين باور را

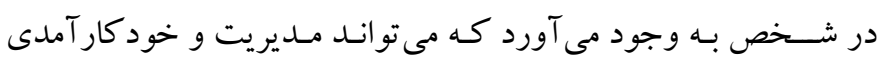
هيجانى خود رادر دست گيرد (f) (I)؛ اين در حالى اسـت كه كود كان و نوجوانان بدسريرست داراى توانايى يايينى در آكاهى هيجانى و مهار آن هسـتند (F-F)، و همين موضسوع دليلى بر اثربخشىى نظم جويى شـناختى هيجان بر دانش هيجانى فرزندان بدسـريرست به شـمار مىرود. همجينين مى توان بيـان كرد كـهـ آموزش نظمجويى شـــــاختى هيجان، راهبردهاى آحَاهانه و غير آكاهانهاى را به افراد مى آموزد كه براى افزايش، حفظ، و كاهش مؤلفه هاى هيجانى، رفتارى، و شـناختى، يكك بِاسخ هيجانى به كار برده مىشـود (سا). يُاســخ هاى هيجانى اطلاعات مهمى درباره تجربه فرد

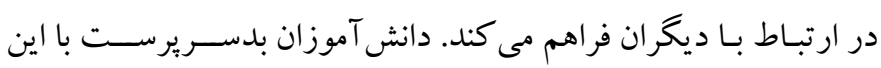
اطلاعات آموختند كه در مواجهه با هيجانات جهه واكنشـى نشــان دهند،

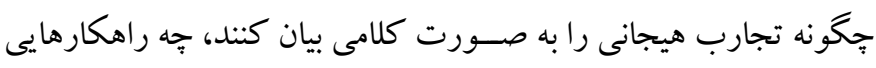
رادر ياسـخ به هيجانات به كار برند، و در زمينه هيجانهاى خاص جّكونه بـا ديخران رفتار كنند. تمام اين روندها با بهبود دانش هيجانى امكانيذير اسـت. علاوه بر اين آموزش نظم جويى شـناختى هيجان سـبب مىشـود، دانش آموزان بدسـريرست ضمن يذيرش هيجانات خود به دنبال تسكين

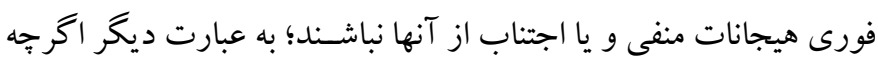
فرد نمى توانـد شــرايط زنـدكى خود را تغيير دهد ولى مى تواند شــدت واكنش هاى هيجانى خود را نسبت به موقعيتهاى تنش آور و رويدادهاى زنـدكى، تغيير دهد. بر اين اســاس آموزش نظمجويى شــناختى هيجان مى تواند با آكًاه كردن دانش آموزان بدسـريرسـت از هيجانهاى مثبت و 


\section{References}

1. Okorodudu GN. Influence of parenting styles on adolescent delinquency in delta central senatorial district. Edo Journal of Counselling. 2010; 3(1): 5886. [Link]

2. Saffarhamidi E, Hosseininan S, Zandipour T. The effect of positive thinking education on the perceived competency and social skills of the orphan and mistreated children. Quarterly Journal of Child Mental Health. 2017; 4(1): 13-23. [Persian]. [Link]

3. Finlon KJ, Izard CE, Seidenfeld A, Johnson SR, Cavadel EW, Krauthamer Ewing ES, et al. Emotionbased preventive intervention: Effectively promoting emotion knowledge and adaptive behavior among atrisk preschoolers. Dev Psychopathol. 2015; $27(40$ 1): 1353-1365. [Link]

4. Hesarsorkhi R, Asghari Nekah SM, Lalzdeh Kandekali E, Parvaneh E. Comparison of aggression and emotional knowledge in orphans and abandoned male children with non- orphans male children. Quarterly Journal of Child Mental Health. 2016; 3(2): 77-87. [Persian]. [Link]

5. Röll J, Koglin U, Petermann F. Emotion regulation and childhood aggression: longitudinal associations. Child Psychiatry Hum Dev. 2012; 43(6): 909-923. [Link]

6. Izard CE, King KA, Trentacosta CJ, Morgan JK, Laurenceau J-P, Krauthamer-Ewing ES, et al. Accelerating the development of emotion competence in Head Start children: effects on adaptive and maladaptive behavior. Dev Psychopathol. 2008; 20(1): 369-397. [Link]

7. Sullivan MW, Carmody DP, Lewis M. How neglect and punitiveness influence emotion knowledge. Child Psychiatry Hum Dev. 2010; 41(3): 285-298. [Link]

8. Einipour J, Vahedi S, Hashemi T. Investigation of relationship among emotional control, cognitive emotional regulation and obsessive beliefs in high school girl students of Rasht. Advances in Cognitive Science. 2013; 15(2): 63-71. [Persian]. [Link]

9. Horowitz M, Znoj H. Emotional control theory and the concept of defense: a teaching document. J Psychother Pract Res. 1999; 8(3): 213-224. [Link]

10. Bawi L, Khodabakhshi Koolaee A. Comparison of mental health, happiness, and emotion control with adolescents' residential centers of state welfare organization and family reared adolescents. Salamat Ijtimai (Community Health). 2015; 2(3): 157-164. [Link]

11. Jermann $F$, Van der Linden $M$, d'Acremont $M$, Zermatten A. Cognitive emotion regulation questionnaire (CERQ): Confirmatory factor analysis and psychometric properties of the French translation. Eur J Psychol Assess. 2006; 22(2): 126-131. [Link]

12. $\mathrm{Li} \mathrm{D}, \mathrm{Li} \mathrm{D}, \mathrm{Wu} \mathrm{N}$, Wang $\mathrm{Z}$. Intergenerational transmission of emotion regulation through parents' reactions to children's negative emotions: Tests of unique, actor, partner, and mediating effects. Child Youth Serv Rev. 2019; 101: 113-122. [Link]

13. Kraaij V, Garnefski N. The behavioral emotion regulation questionnaire: development, psychometric properties and relationships with emotional problems and the cognitive emotion regulation questionnaire. Pers Individ Dif. 2019; 137: 56-61. [Link]

14. Malesza M. Stress and delay discounting: The mediating role of difficulties in emotion regulation. Pers Individ Dif. 2019; 144: 56-60. [Link]

15. Benfer N, Bardeen JR, Clauss K. Experimental manipulation of emotion regulation self-efficacy: Effects on emotion regulation ability, perceived effort in the service of regulation, and affective reactivity. $\mathrm{J}$ Contextual Behav Sci. 2018; 10: 108-114. [Link]

16. Herwig U, Opialla S, Cattapan K, Wetter TC, Jäncke L, Brühl AB. Emotion introspection and regulation in depression. Psychiatry Res Neuroimaging. 2018; 277: 7-13. [Link]

17. Kirwan M, Pickett SM, Jarrett NL. Emotion regulation as a moderator between anxiety symptoms and insomnia symptom severity. Psychiatry Res. 2017; 254: 40-47. [Link]

18. Meule A, Fath K, Real RG, Sütterlin S, Vögele C, Kübler A. Quality of life, emotion regulation, and heart rate variability in individuals with intellectual disabilities and concomitant impaired vision. Psychology of Well-Being: Theory, Research and Practice. 2013; 3(1): 1. [Link]

19. Bohlmeijer E, Prenger R, Taal E, Cuijpers P. The effects of mindfulness-based stress reduction therapy on mental health of adults with a chronic medical disease: A meta-analysis. J Psychosom Res. 2010; 68(6): 539-544. [Link]

20. Zarotti N, Simpson J, Fletcher I, Squitieri F, Migliore S. Exploring emotion regulation and emotion recognition in people with presymptomatic Huntington's disease: The role of emotional awareness. Neuropsychologia. 2018; 112: 1-9. [Link]

21. Haynos AF, Hill B, Fruzzetti AE. Emotion regulation training to reduce problematic dietary restriction: An experimental analysis. Appetite. 2016; 103: 265-274. [Link]

22. Jakubczyk A, Trucco EM, Kopera M, Kobyliński P, Suszek H, Fudalej S, et al. The association between 
impulsivity, emotion regulation, and symptoms of alcohol use disorder. J Subst Abuse Treat. 2018; 91 : 49-56. [Link]

23. Zlomke KR, Hahn KS. Cognitive emotion regulation strategies: Gender differences and associations to worry. Pers Individ Dif. 2010; 48(4): 408-413. [Link]

24. Delavar A. Methods in psychology and educational sciences. Second edition. Tehran: Virayesh pub; 2012, p: 99. [Persian].

25. Hosseini J, Shahgholiyan M. Emotional expressiveness, emotional control, and ambivalence over emotional expressiveness in runaway and normal girls. Counseling Culture and Psycotherapy. 2014; 5(17): 117-134. [Persian]. [Link]
26. Tajik Zadeh F, Sadeghi R. The study of emotional control styles as predictor aggression in girl students. Quarterly Journal of Women and Society. 2014; 4(16): 97-114. [Persian]. [Link]

27. Morgan JK, Izard CE, King KA. Construct validity of the emotion matching task: preliminary evidence for convergent and criterion validity of a new emotion knowledge measure for young children. Soc Dev. 2009; 19(1): 52-70. [Link]

28. Gross JJ, Thompson RA. Emotion regulation: Conceptual foundations. In: Gross JJ, editor. Handbook of emotion regulation. New York, NY, US: The Guilford Press; 2007, p: 3-24. [Link] 